\title{
KAJIAN CSR MELALUI SUDUT PANDANG PERENCANAAN TRANSAKTIF: STUDI KASUS PERENCANAAN CSR DI INDONESIA

\author{
Muhammad Taufiq ${ }^{1}$ \\ Suhirman ${ }^{2}$ \\ Benedictus Kombaitan 4
} \\ Tubagus Furqon Sofhani ${ }^{3}$
}

\author{
1,2,3,4 Sekolah Arsitektur, Perencanaan dan Pengembangan Kebijakan, Institut Teknologi Bandung \\ ${ }^{1}$ Pemerintah Kabupaten Langkat, Provinsi Sumatera Utara \\ 1taufiqlangkat@s.itb.ac.id
}

\begin{abstract}
CSR gain local community development. However, its practice is contradictive, partially not only beneficial but also it does not bring significant benefits. CSR planning as an integration tool for the interest between corporate and local community is the main driving factor for its effectivity implementation. The article presents a communicative approach in CSR planning by combining both the concept of CSR and transactive planning. The general view that Corporate dominating CSR planning is the main criticism which causes its policy has not a significant impact. How is the conceptualization of CSR planning approach, which communicates with the beneficiary community, this article aims to reveal its understanding. The study evaluates the transactive process on CSR planning, through descriptive qualitative analysis of literature. The result proposes a CSR planning model based on transactive planning approach. The article also initiates that CSR planning is a transactive process which raised through knowledge transaction between planner and community toward towards legitimacy in increasing community support for company operations.
\end{abstract}

Keywords : CSR, Indonesia, transactive planning.

\begin{abstract}
Abstrak
CSR mendatangkan manfaat dalam mensejahterakan masyarakat lokal. Namun praktiknya kontradiktif, secara parsial sangat membantu, namun juga tidak mendatangkan dampak signifikan. Perencanaan CSR sebagai alat pengintegrasi kepentingan antara perusahaan dan masyarakat lokal adalah faktor penggerak utama efektivitas implementasinya. Artikel ini menyuguhkan pendekatan komunikatif dalam perencanaan CSR dengan memadukan antara konsep CSR dengan konsep perencanaan transaktif. Pandangan umum bahwa perencanaan CSR didominasi perusahaan menjadi kritik utama yang menyebabkan kebijakan CSR tidak berdampak signifikan. Bagaimana konseptualisasi pendekatan perencanaan CSR yang benar-benar berkomunikasi dengan komunitas penerima manfaat, artikel ini bertujuan mengungkap pemahaman hal tersebut. Kajian ini mengevaluasi proses transaktif pada praktik perencanaan CSR, melalui metode analisis deskriptif kualitatif literatur. Hasil kajian mengusulkan model perencanaan CSR dari sudut pandang perencanaan transaktif. Artikel juga menginisiasi bahwa perencanaan CSR adalah suatu proses transaktif yang dibangkitkan melalui
\end{abstract}

\section{Article History Received : 2018-11-05 Revised : 2019-11-15 Accepted : :2019-12-20

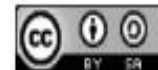

This is an open access article under the CC-BYSA License 
transaksi pengetahuan antara perencana dan komunitas menuju legitimasi dalam meningkatkan dukungan komunitas terhadap operasionalisasi perusahaan

Kata kunci: CSR, Indonesia, perencanaan transaktif.

\section{Pendahuluan}

Perhatian terhadap Corporate

Social Responsibility (CSR) meningkat seiring adanya integrasi kepentingan perusahaan dan stakeholder dalam perencanaannya (Jenkins \& Yakovleva, 2006, hlm. 272). CSR menjadi alat inisiatif bisnis dalam mewujudkan sistem manajemen terintegrasi (Asif, Searcy, Zutshi, \& Fisscher, 2013, hlm. 7). Perencanaannya merupakan tarikulur manfaat ekonomi bagi perusahaan (Banerjee, 2014, hlm. 3). Tampaknya proses ini bersifat top-down ketika perencanaan CSR yang berisikan kegiatan-kegiatan pengembangan masyarakat dipaksakan tanpa benarbenar berkomunikasi dengan komunitas penerima manfaat. Dampaknya kebijakan CSR menjadi dilema saat diimplementasikan (Abuya, 2016, hlm. 485). Oleh karena itu, sangat penting untuk memahami bagaimana proses perencanaan CSR yang benar-benar dikomunikasikan dengan komunitas.

Sejauh ini literatur tentang perencanaan CSR menekankan orientasi hasil yang didominasi keputusan sepihak perusahaan (Asif dkk., 2013; Banerjee, 2014; Hamann, 2003). Namun sedikit yang membahas bagaimana jika prosesnya bersifat komunikatif dengan menitikberatkan pada transaksi informasi antara perencana CSR dan komunitas. Artikel ini menanyakan bagaimana konseptualisasi perencanaan CSR dalam konteks transaktif, yakni pendekatan yang memandang perencanaan CSR sebagai proses transaksi informasi dalam menjembatani perbedaan gap pengetahuan antara perencana (perusahaan) dan klien (komunitas).

Untuk menjawab pertanyaan tersebut, artikel ini membangun model yang berasal dari tinjauan literatur praktik-praktik CSR di Indonesia dan 
perencanaan transaktif, serta menganalisanya secara deskriptif kualitatif. Analisis kasus ini menekankan interaksi antara pihak perusahaan (perencana CSR) dan komunitas penerima manfaat. Artikel bertujuan mendapatkan pemahaman tentang perencanaan CSR dalam konteks pertukaran informasi dalam mendukung hasil kebijakan yang lebih baik.

\section{Tinjauan Pustaka}

\subsection{CSR: Suatu integrasi kepentingan}

CSR diartikan sebagai upaya perusahaan dalam mengintegrasikan bidang sosial dan lingkungan (Ranängen, 2015). Perusahaan menggunakan CSR untuk mendapatkan simpati stakeholder di sekitar tempat operasionalisasi usahanya. Dimensi sosial menjadi salah satu identitas CSR yang menghubungkan antara bisnis dan sosial melaui "kontribusi terhadap kondisi masyarakat yang lebih baik dan dengan mengintegrasikan kepedulian sosial dalam operasi bisnisnya" (Dahlsrud, 2008, hlm. 4).

CSR sarat dengan kepentingan dari kedua belah pihak baik masyarakat maupun perusahaan. Masyarakat memandang CSR sebagai bantuan wajib yang diberikan oleh perusahaan (karena dilindungi aturan). Sedangkan perusahaan beranggapan CSR sebagai pengeluaran yang mana selain untuk memenuhi aturan berlaku juga bermanfaat dalam mendukung operasionalisasi usahanya. Perencanaan CSR menjadi jembatan antara kepentingan yang ditimbulkan kedua pandangan ini.

Penelitian mengenai keterlibatan CSR di manca negara telah mempelajari hubungan antara pemangku kepentingan, masyarakat dan perusahaan, baik melalui penelitian empiris atau melalui kajian konseptual perbandingan teori. Namun, umumnya dilakukan melalui perspektif strategi CSR yang sebagian besar merupakan domain perusahaan dan bisnis, seperti halnya melalui sudut pandang pendefinisian CSR (Dahlsrud, 
2008), integrasi CSR ke dalam proses bisnis perusahaan (Asif dkk., 2013) batasan struktural dan fungsional dalam kerangka CSR (Banerjee, 2014), kerangka perkembangan CSR dari filantropi dan dampak mitigasi menuju kemitraan sosial (Hamann, 2003), manajeman pemangku kepentingan (Ranängen, 2015, 2017). Sekelompok ahli lainnya mengkaji CSR dari sudut pandang perusahaan, yang sebagian besar berfokus pada tingkat strategis dan niat (Dobers, 2009), pendekatan penerapan praktis integrasi CSR dalam proses inti bisnis (Ranängen \& Zobel, 2014), sudut pandang internal perusahaan (Kemp, 2010), pemetaan pemangku kepentingan perusahaan (Freeman, Harrison, \& Wicks, 2007), serta kontribusi perusahaan terhadap pengembangan dan keterlibatan masyarakat (Hedin \& Ranängen, 2017). Manajemen strategis CSR kekurangan penelitian yang menyentuh perspektif perencanaan dalam domain publik, yakni bagaimana perencanaan CSR dilakukan melalui perspektif perencanaan transaktif dengan tujuan menemukan kesenjangan pengetahuan antara perusahaan dan komunitas.

Sejumlah publikasi telah menguraikan bagaimana manajemen strategis CSR dilakukan. Asif dkk. (2013, hlm. 16) berargumen bahwa sistem manajemen terintegrasi memunculkan kecenderungan pendekatan top-down sebagai inisiatif bisnis dan pendekatan bottom-up sebagai inisiatif masyarakat. CRS merefleksikan kemitraan antara perusahaan, pemerintah dan masyarakat dalam mendukung pembangunan berkelanjutan. Di sini, "pemerintah mengusulkan acuan perencanaan regional dan infrastruktur, dimana masyarakat lokal dapat memasok tenaga kerja dan bahan bangunan dan LSM dapat memberikan keahlian audit eksternal" (Hamann, 2003, hlm. 245). CSR menjadi identitas perusahaan yang direncanakan internal (Tourky, Kitchen, \& Shaalan, 2019). Teori pemangku kepentingan membantu perusahaan mengidentifikasi stakeholder dalam memajukan praktik 
CSR (Ranängen, 2017, hlm. 16). Tampaknya pendekatan-pendekatan tersebut memfokuskan tentang bagaimana mengintegrasikan CSR ke dalam proses bisnis, tanpa benar-benar memperhatikan bagaimana berlangsungnya rumusan CSR dengan melibatkan komunikasi antara perencana CSR dan komunitas penerima manfaat

Ada kebutuhan terhadap pemahaman yang lebih baik bagi perusahaan berkenaan keinginan masyarakat untuk terlibat dalam proses pengambilan keputusan melalui pendekatan yang lebih pro aktif (Hedin \& Ranängen, 2017, hlm. 630). Inisiatif bottom-up bagi CSR menjadi penting ketika masing-masing aktor berdiri pada sudut pandang berlainan, maka komunitas dapat terlibat dalam proses penetapan prioritas CSR (Adanhounme, 2011, hlm. 107). Namun, bagaimana memahami hal ini masih memerlukan kajian khusus.

CSR menjadi integrasi kepentingan antara perusahaan, pemerintah dan masyarakat. Artikel ini lebih memfokuskan hubungan antara perusahaan dan komunitas. Perusahaan dan komunitas memiliki kepentingan dalam praktik CSR. Perencanaan CSR menjadi alat yang menjembatani kepentingan tersebut. Kegiatankegiatan yang ditawarkan oleh perusahaan kepada masyarakat menjadi fokus dalam perencanaan CSR. Pilihan kegiatan dan prioritasnya menjadi materi utama pembahasan perencanaan CSR.

\subsection{Perencanaan: alat pengambilan keputusan}

Kebutuhan akan keilmuan perencanaan merupakan dampak dari meningkatnya permasalahan di masyarakat yang menghendaki suatu sikap tindakan yang berencana di berbagai lini kehidupan (Sujarto, 1988). Pada awal perkembangannya teori perencanaan dikenal sebagai pengetahuan dalam merancang, membangun dan menata kota, atau lebih dikenal dengan planologi. Perencanaan pada masa itu dikenal sebagai pengetahuan merancang kota atau bangunan yang ada di dalamnya, 
sebagai upaya mengatasi permasalahan dan memenuhi keinginan masyarakat, dengan konsep-konsep yang tematik berdasarkan kajian, teknik dan susunan proses pelaksanaan kegiatan, sebagai contoh konsep pembangunan garden city, broadacre city, city beautiful movement, radiant city, dsb.

Perencanaan merupakan proses menentukan tindakan yang tepat di masa mendatang, mencari tau melalui pendekatan teknis atau aplikasi ilmu pengetahuan dalam menentukan keputusan, serta untuk mengetahui temuan sains sosial bagi perencana sebagai teknokrat yang fokus pada teori substantif dan teori prosedural (Davidoff \& Reiner, 1962; Faludi, 1973). Dengan demikian, maka perencanaan menggunakan praktek strategi apa yang harus diadopsi dan bagaimana partisipasi masyarakat atau pemangku kepentingan dilakukan, lebih bersifat demokrasi (Friedmann, 2003). Esensi dari perencanaan adalah sebagai alat pengambilan keputusan, karena perencanaan dibangun dengan misi dan tujuan tertentu untuk selanjutnya melakukan kajian dan menentukan opsi-opsi penyelesaian masalah dalam bentuk strategi, serta dijadikan kebijakan dalam implementasi perencanaan.

Perencanaan sebagai ilmu multi disiplin, memberikan peluang besar bagi pengembangannya. Umumnya teori dalam dunia perencanaan terbagi atas dua bentuk yakni teori perencanaan substantif (theory in planning), berkenaan dengan keahlian teknis dan pengetahuan interdisipliner yang digunakan dalam perencanaan yang dipinjam dari disiplin multi ilmu, dan teori perencanaan prosedural (theory of planning) berkenaan dengan prosedur yang ditempuh dalam proses perencanaan, seperti mendefinisikan dan menggunakan metode yang tepat dalam mengambil keputusan (Faludi, 1973; Yiftachel, 1989). Pada perkembangannya, pembahasan teori perencanaan cenderung berfokus tentang teori prosedural (proses) perencanaan (Taylor, 1998). 
Seiring perkembangan teori perencanaan prosedural, sebagaimana yang dihadapi oleh kota bukan hanya permasalahan tata bangunan atau infrastruktur saja, namun lebih jauh terkait dengan komunitas perkotaan itu sendiri, serta hal-hal lain yang bersinggungan dengan perencanaan. Teori perencanaan mengalami asimilasi perkembangan dari berbagai bentuk pandangan logika yang mendasarinya. Terdapat beberapa bentuk perencanaan prosedural, diantaranya perencanaan sinoptik oleh Herbert Simon tahun 1950-an, perencanaan inkremental Charles Lindblom tahun 1960-an, mixscanning Amitai Etzioni dan praktik reflektif Donald Schoen (dalam Friedmann, 2003, hlm. 8), serta perencanaan advokasi (Davidoff, 1965). Disamping itu juga terdapat perencanaan transaktif (Friedmann, 1973, 2011), sebagai awal adanya perencanaan berbasis komunikatif yang mengadopsi pemahaman rasionalitas substansial Karl Mannheim (Sager, 1993, hlm. 91).

\subsection{Perencanaan transaktif: menjembatani gap pengetahuan perencana dan klien}

Perencanaan transaktif adalah perencanaan yang berdasarkan dialog tatap muka antara perencana dan masyarakat, serta melihat komunitas sebagai fokus perencanaan. "Perencanaan transaktif menjembatani gap antara pengetahuan teknis perencana dan kliennya melalui komunikasi ... menemukan cara untuk menggabungkan intelegensi ilmiah dan teknis dengan pengetahuan pribadi pada titik kritis intervensi sosial" (Friedmann, 1973, hlm. 171-190).

Secara epistemologi perencanaan CSR merupakan proses transaksional (Taufiq, Kombaitan, \& Putro, 2018, hlm. 136). Perencanaan transaktif memandang perencanaan sebagai transaksi informasi antara perencana dan klien dimana perencana berkontribusi terhadap keahliannya (konsep, teori, analisis, perspektif baru dan prosedur sistematis), sedangkan klien berkontribusi terhadap 
pengetahuan lokal dan tujuan yang diinginkan (norma, alternatif realistis, prioritas, penilaian kelayakan dan detail operasional) (Friedmann, 1973). Perencanaan transaktif berfokus pada kontak tatap muka antara perencana dan pihak yang terkena dampak, lebih menekankan pada proses dialog, kolaborasi, partisipatif dan pembelajaran bersama.

Perencanaan transaktif dapat dikatakan sebagai perencanaan dalam domain publik, karena merupakan bentuk perencanaan yang implementasinya berada pada ranah sosial atau di masyarakat. Hal ini dilakukan dengan mengintegrasikan berbagai kepentingan untuk mendapat jalan keluar berdasarkan pembelajaran sosial. Dalam kajian artikel ini, kasusnya adalah perencanaan CSR bagi masyarakat lokal yang merupakan salah satu bentuk perencanaan dalam domain publik. Pembahasannya cenderung berfokus pada hubungan antara perusahaan, masyarakat dan pemerintah dalam rumusan kebijakan CSR.
Istilah perencanaan dalam domain publik di dunia perencanaan awalnya diperkenalkan oleh John Friedmann. Ia mengklasifikasikan tradisi pemikiran perencanaan menjadi empat jenis, yakni 1) reformasi sosial (social reform), berfokus pada peran negara dalam memandu perencanaan di masyarakat, 2) analisis kebijakan (policy analysis), perencanaan berfokus pada perilaku organisasi besar, khususnya bagaimana mereka meningkatkan kapasitasnya dalam membuat keputusan rasional, 3) pembelajaran sosial (social learning), perencanaan berfokus pada penanggulangan kontradiksi antara teori dan praktik, atau pengetahuan dan tindakan, dan 4) mobilisasi sosial (social mobilization), perencanaan sebagai bentuk tindakan kolektif yang muncul sebagai bentuk politik tanpa mediasi pengetahuan sistematis (sains), analisis ilmiah dalam bentuk pembelajaran sosial berperan penting dalam proses transformatif ini (Friedmann, 1987). 


\begin{abstract}
Perencanaan CSR adalah bentuk perencanaan dalam domain publik yang cenderung diklasifikasikan sebagai tradisi pembelajaran sosial. Perencanaan CSR mengintegrasikan antara teori dan praktik, dimana konsep-konsep CSR direfleksikan ke dalam gagasan/ kebijakan perencanaan CSR untuk selanjutnya diimplementasikan melalui tindakan. Permasalahan yang terkandung dalam implementasi CSR dapat dipahami melalui logika pembelajaran sosial dimana ada kesenjangan pengetahuan antara perencana (dalam hal ini perusahaan) dengan objek CSR (masyarakat penerima bantuan). Melalui teori perencanaan transaktif, kondisi ini dipandang sebagai bentuk dialogis antara perencana dan klien yang belum terjadi. Dengan kata lain, proses transaktif belum terjadi antara kedua belah pihak.
\end{abstract}

\section{Metode Penelitian}

Muhammad Taufiq, Suhirman, Tubagus Furqon Sofhani dan Benedictus Kombaitan Kajian CSR melalui ...
Artikel ini menggunakan teknik analisis konten (literatur) secara deskriptif kualitatif. Data studi kasus yang digunakan bersumber dari jurnal dan sumber lain yang berhubungan. Beberapa konsep yang dikaji dalam artikel diantaranya: CSR, perencanaan transaktif, perencanaan dalam domain publik, fakta empiris (data sekunder) dan integrasi konsep. Artikel ini adalah suatu tinjauan teoretis yang mengusulkan pemahaman kepada pembacanya. Kajian didominasi pemikiran sepihak penulis dalam menginterpretasikan ide-ide tentang konstruksi pemahaman proses transaktif dalam perencanaan CSR.

\section{Hasil dan Pembahasan}

\subsection{CSR dan Kompleksitasnya}

Perjalanan legalitas CSR di Indonesia tidak terlepas dari perkembangan peraturan tentang perseroan terbatas. CSR bukan merupakan hal yang wajib pada UU No. 1/ 1995 tentang Perseroan Terbatas. Namun, setelah berlakunya aturan terbaru yakni UU No. 40/ 2007 tentang Perseroan Terbatas, maka ada 
kewajiban perusahaan dalam menyelenggarakan CSR bagi dimensi sosial. Terlebih lagi bagi usaha yang berhubungan dengan eksplorasi sumber daya alam seperti perusahaan pertambangan, disamping menyelenggarkan CSR dimensi sosial, mereka juga harus menyelenggarakan CSR dimensi lingkungan. Dengan demikian, maka menjadi keharusan perusahaan untuk mengeluarkan CSR yang dibebankan dari keuntungannya.

Besaran CSR itu sendiri teknisnya belum. Tidak ada aturan yang eksplisit menjelaskan berapa besaran CSR yang harus diberikan perusahaan karena sifatnya adalah sukarela. Pelaksanaan CSR merupakan beban lain perusahaan, dimana sebenarnya perusahaan juga wajib membayar berbagai bentuk pajak yang dikenakan kepadanya. Maka, pertimbangan tersebut menjadi landasan bagi perusahaan berkenaan berapa besaran CSR yang dikeluarkan, disamping dipengaruhi oleh keuntungan dan kondisi ekonominya. Hal inilah yang menyebabkan CSR sulit untuk di audit dan diketahui besaran sesungguhnya (secara reguler) karena bersifat tentatif, dengan kata lain besaran CSR tidak bisa dipaksakan oleh semua pihak. Negatifnya, hal ini memberi keleluasaan bagi perusahaan untuk memberikannya sekehendak hati tanpa proporsi yang jelas (Joseph dkk., 2016).

Adanya CSR difungsikan sebagai alat meningkatkan harmonisasi antara masyarakat dan perusahaan akibat dari adanya kerugian sosial yang diderita oleh masyarakat (akibat eksternalitas negatif operasional perusahaan tertentu, biasanya pada perusahaan pertambangan seperti kecenderungan berpotensi pencemaran tanah, air dan udara, serta aktivitas keseharian usahanya). Pemahaman antara hubungan perusahaan dan masyarakat ini adalah kompleks. Di satu sisi perusahaan ingin terus melanggengkan usahanya dengan tujuan meningkatkan profit, di sisi lain adanya keinginan masyarakat agar perusahaan bertanggung jawab dari 
dampak negatif yang ditimbulkan operasional perusahaan. CSR sebagai penjembatan permasalahan tersebut juga memiliki keterbatasan dimana tidak adanya aturan eksplisit seberapa besar yang harus dikeluarkan untuk masyarakat.

\subsection{Perencanaan CSR: transaksi pengetahuan}

Perencanaan CSR selayaknya menjadi wahana transaksi informasi antara perencana dan klien. Dalam hal ini perencana diperankan oleh perusahaan dan klien diperankan oleh komunitas penerima manfaat. Melalui konsep perencanaan transaktif, selayaknya perencana CSR memberikan kesempatan bagi komunitas untuk berpartisipasi dalam penentuan kegiatan-kegiatan apa saja yang akan diberikan agar maksud pelaksanaan CSR memenuhi kebutuhan sebenarnya yang diinginkan masyarakat. Ada dua pengetahuan yang berperan dalam hal ini yakni pengetahuan yang dibawa perencana dan pengetahuan yang dibawa komunitas.
Pengetahuan perencana didasari oleh beberapa pertimbangan diantaranya pengetahuan teknis terhadap prosedur penyelanggaraan CSR, keinginan perusahaan berkenaan kegiatan yang ingin dilakukan serta jumlah CSR yang dikucurkan. Sedangkan pengetahuan komunitas terdiri dari keinginan masyarakat, pengetahuan lokal dan tujuan yang ingin dicapai.

Dalam perencanaan CSR dilakukan komunikasi bersifat teori untuk selanjutnya diimplementasikan menjadi penyelenggaraan CSR yang bersifat praktik. Konsep perencanaan transaktif mementingkat kedua identitas ini, yakni kesesuaian antara teori dan praktik (Gambar 1). Dengan instrumen utamanya adalah komunikasi langsung dengan masyarakat, bukan melalui kebijakan langsung perusahaan. Untuk mengimplementasikannya, selayaknya perusahaanmembentuk suatu divisi khusus atau tugas khusus yang melekat pada karyawannya sebagai petugas perencana CSR. Perencana ini yang 
selanjutnya akan berkomunikasi dengan komunitas. Di sisi lain komunitas juga bisa diwakili oleh perwakilan (komunitas tradisional) yang benar-benar mengemban amanat masyarakat yang diwakilinya dengan prasyarat memiliki pengetahuan lokal tentang apa-apa yang diinginkan masyarakat.

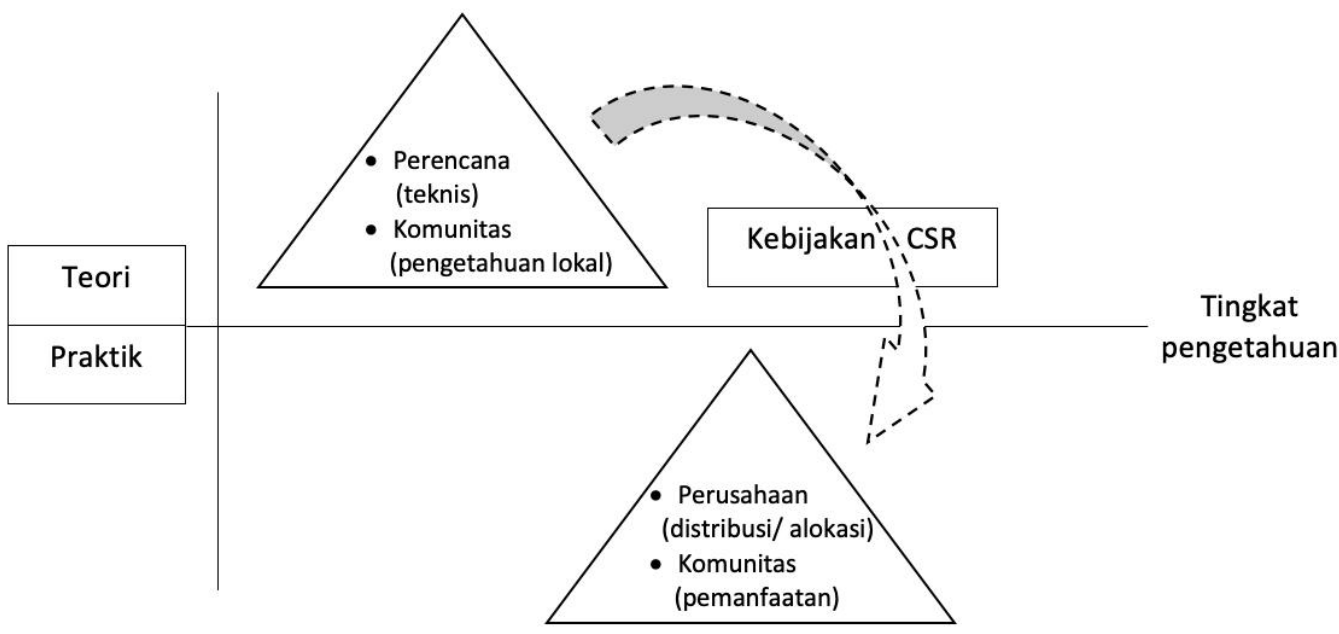

Gambar 1

Penyelenggaraan CSR sudut pandang perencanaan transaktif.

Sumber: Olahan penulis

Di ranah teoretik perencana dan komunitas melakukan transaksi pengetahuan melalui diskusi forum dalam merumuskan kebijakan CSR. Perencana menggunakan keahlian teknisnya sedangkan komunitas menggunakan pengetahuan lokalnya. Dapat dipahami bahwa apapun hasil diskusi tersebut merupakan masukan bagi perusahaan dalam memutuskan kebijakan CSR. Jadi, pembuat keputusan CSR tetap diserahkan kepada perusahaan.

Dalam memutuskan kebijakan berkenaan kegiatan-kegiatan apa saja yang ingin diprioritaskan untuk dilaksanakan, perusahan memiliki dasar yang kuat dan legitimasi dari komuntas. Legitimasi yang didapat melalui diskusi forum ini menjadikan implementasi CSR cenderung akan berjalan dengan lancar. Implementasi 
CSR diperankan oleh perusahaan dalam distibusi dan alokasi sumberdaya seperti kegiatan-kegiatan pemberdayaan masyarakat. Sedangkan komunitas berperan dalam pemanfaatan bantuan tersebut dengan baik.

\subsection{Studi kasus: perencanaan CSR di Indonesia}

Studi Kartikawangi (2017, hlm.

38) mengungkapkan akomodasi komunikasi menuju kerjasama yang konstruktif menjadi tuntutan dalam mewujudkan CSR secara optimal. Dalam mewujudkan kesejahteraan di masyarakat, CSR penting dilakukan melalui hubungan antar perusahaan dan masyarakat (Kriyantono, 2015, hlm. 320). Praktik CSR di Indonesia memerlukan konsep interpretasi yang tepat sebagai tuntutan wajib perusahaan (Waagstein, 2011, hlm. 455). Pendekatan komunikasi menjadi alternatif dalam optimalisasi perencanaan CSR.

Ada beberapa jenis pengetahuan yang dapat ditransaksikan dalam perencanaan CSR. Studi Kartikawangi (2017) yang mengidentifikasi CSR kolaboratif di Indonesia berargumen bahwa kompetensi strategis dan taktis menjadi perhatian dalam perencanaan CSR. Namun, tidak secara terperinci menjelaskan apa yang dimaksud dengan kompetensi tersebut dan pengetahuan-pengetahuan apa yang berhubungan dengannya. Melalu tiga studi kasus CSR yang disampaikan, yakni PT. Aqua Danone, PT. Unilever Indonesia dan PT. Astra International menyiratkan bahwa perencanaan CSR digagas melalui komunikasi. Aqua melalui divisi CSR internal mengeluarkan kebijakan 'aqua lestari' yang mana merupakan produk dari identifikasi stakeholder dan masalah yang dihadapi perusahaan. Identifikasi ini merupakan pengetahuan yang dibawa perencana dalam mengkomunikasikan kebijakan CSR. Kasus Aqua dapat dicontohkan seperti pengetahuan tentang masalah-masalah seperti akses air, limbah, konservasi, transportasi dan pengembangan 
masyarakat (Kartikawangi, 2017, hlm. 41). Pengetahuan tersebut dapat dikatakan sebagai kompetensi strategis yang dapat dikomunikasikan dengan komunitas.

Melalui pendekatan transaktif, komunitas dan perusahaan melakukan transaksi informasi tentang hal-hal apa yang dibutuhkan oleh masyarakat dan hal-hal apa yang kemudian mendukung perusahaan. Ini menjadi suatu proses transfer pengetahuan antara perencana dan komunitas. Sebagaimana yang dilakukan oleh Astra dengan bernegosiasi dan mengakomodasi nilai-nilai dalam mencapai konsep terpadu perusahaan, produk dan penerimaan masyarakat (Kartikawangi, 2017, hlm. 43). Di sini komunitas berkontribusi terhadap pengetahuan tentang norma, kebutuhan, tujuan, individu sasaran dan kearifan lokal (Tabel 1). Proses transaktif menjadi jembatan penghubung antara perusahaan dan komunitas. Sebagaimana yang dilakukan oleh Unilever, yakni bekerja dalam kemitraan khususnya pada inisiatif pertanian berkelanjutan dan pertanian kecil (Kartikawangi, 2017, hlm. 42).

Tabel 1

Proses transaktif dalam perencanaan CSR

\begin{tabular}{|c|c|c|}
\hline Tingkatan pengetahuan & Tipe transaksi & Hasil transaksi \\
\hline Teori & $\begin{array}{l}\text { Perencana: Budaya dan nilai perusahaan } \\
\text { (kompetensi strategis), prosedur, cakupan } \\
\text { bantuan, prioritas kegiatan } \\
\text { Komunitas: Norma, kebutuhan, tujuan, } \\
\text { individu sasaran, kearifan lokal, kegiatan- } \\
\text { kegiatan }\end{array}$ & Transfer pengetahuan \\
\hline \multirow[t]{2}{*}{ Praktik } & $\begin{array}{l}\text { Perencana: Penyelenggaraan kegiatan, } \\
\text { distribusi dan alokasi sumber daya }\end{array}$ & Legitimasi \\
\hline & $\begin{array}{l}\text { Komunitas: Partisipasi aktif sebagai } \\
\text { pengguna }\end{array}$ & \\
\hline
\end{tabular}

\section{Sumber: Olahan penulis}

Pertukaran informasi dilakukan

dalam diskusi-diskusi yang

diselenggarakan antara perencana dan komunitas. Proses ini menuju pembelajaran bersama. CSR bukan hanya dipandang sebagai pemberian 
bantuan, namun mencerminkan kesesuaian antara perusahaan dan lingkungannya. Transfer pengetahuan antara perencana dan komunitas mampu mewujudkan hal tersebut. Implementasi hal ini bagi perusahaan menjadikan perusahaan tersebut lebih terbuka dalam menanggapi hal-hal yang benar-benar dibutuhkan masyarakat sekitarnya.

Kendala yang dihadapi selama ini adalah susahnya komunikasi langsung antara komunitas dengan perusahaan dalam merumuskan prioritas kegiatan CSR. Adanya anggapan bahwa CSR merupakan kebijakan yang ditentukan oleh perusahan menjadikannya suatu ekslusifitas yang dimiliki perusahaan. Selama kebijakan yang dilakukan benar-benar menyentuh keinginan objek CSR mungkin pendapat ini bisa dikesampingkan, namun ketika hal ini tidak sesuai maka niat baik yang diusahakan terbuang sia-sia.

Banyak pihak tidak menyadari mengapa CSR yang diberikan tidak berdampak positif terhadap dukungan komunitas terhadap jalannya operasionalisasi perusahaan. CSR yang tidak tepat sasaran dan tidak memenuhi legitimasi komunitas lokal menjadi penyebab hal tersebut. Kriyantono berargumen bahwa CSR merupakan alat komunikasi guna meningkatkan reputasi (Kriyantono, 2015, hlm. 326). Proses transaktif berperan disini. Pendekatan ini menghasilkan legitimasi CSR di masyarakat, yang mana selanjutnya akan meningkatkan dukungan mereka terhadap operasionalisasi perusahaan.

$$
\text { Studi Kriyantono }
$$

mengindikasikan bagaiamana hubungan masyarakat yang baik mengikat legitimasi masyarakat terhadap penyelenggaraan CSR. Implementasi CSR sangat ditentukan oleh legitimasi tersebut. Partisipasi aktif yang datang dari masyarakat mencerminkan dukungannya terhadap operasionalisasi perusahaan. Mungkin ini yang dimaknai dengan "CSR sebagai alat komunikasi untuk mendapatkan reputasi"(Kriyantono, 2015, hlm. 326). 


\section{Simpulan}

Artikel ini menawarkan kontribusi teoritis bagi bidang perencanaan CSR. Secara teoritis, ini mengusulkan model yang menghubungkan literatur perencanaan transaktif dan manajemen CSR untuk menjelaskan proses transaksi pengetahuan antara perencana CSR dan komunitas penerima manfaat. Kajian ini membangun suatu pemahaman yang mengkombinasikan antara konsep CSR yang umumnya berada di ranah manajemen bisnis dan konsep perencanaan transaktif sebagai bentuk teori perencanaan prosedural yang umumnya merupakan pembahasan studi perencanaan wilayah dan kota. Model yang diusulkan mengidentifikasi tiga komponen utama dari proses transaktif dalam perencanaan CSR yaitu: tingkat pengetahuan (pengetahuan teori dan praktik), tipe transaksi (pengetahuan yang bersumber dari perencana dan komunitas), dan hasil transaksi (keluaran yang didapat).
Model ini mungkin masih prematur dan memiliki keterbatasan yang memerlukan penyempurnaan dikemudian hari. Namun, setidaknya bisa menjadi referensi bagi penggiat praktik maupun peneliti di bidang CSR. Penelitian lebih lanjut dalam koridor yang sama membutuhkan kajian empiris tentang bagaimana peran aktor terlibat dalam melakukan transfer pengetahuan pada kasus perencanaan CSR, dan bagaimana para agen (baik dari kalangan perencana maupun komunitas) mampu mensintesis pengetahuan teoretis dan praktis yang dimilikinya.

\section{DAFTAR PUSTAKA}

Abuya, W. O. (2016). Mining conflicts and corporate social responsibility: Titanium mining in Kwale, Kenya. The Extractive Industries and Society, 3(2), 485-493.

Adanhounme, A. B. (2011). Corporate Social Responsibility In Postcolonial Africa: Another Civilizing Mission? Journal of Change Management, 11(1), 91110. https://doi.org/10.1080/1469701 
7.2011 .548945

Asif, M., Searcy, C., Zutshi, A., \& Fisscher, O. A. M. (2013). An integrated management systems approach to corporate social responsibility. Journal of Cleaner Production, 56, 7-17.

Banerjee, S. B. (2014). A critical perspective on corporate social responsibility: Towards a global governance framework. Critical perspectives on international business, 10(1/2), 84-95.

Dahlsrud, A. (2008). How corporate social responsibility is defined: An analysis of 37 definitions. Corporate social responsibility and environmental management, 15(1), 1-13.

Davidoff, P. (1965). Advocacy and pluralism in planning. Journal of the American Institute of Planners, 31(4), 331-338.

Davidoff, P., \& Reiner, T. A. (1962). A choice theory of planning. Journal of the American Institute of Planners, 28(2), 103-115.

Dobers, P. (2009). Corporate social responsibility: Management and methods. Corporate Social Responsibility and Environmental Management, 16(4), 185-191.

Faludi, A. (1973). Planning theory. Pergamon Press.

Freeman, R. E., Harrison, J. S., \& Wicks, A. C. (2007). Managing for stakeholders: Survival, reputation, and success. Yale University Press.

Friedmann, J. (1973). Retracking America: A theory of transactive planning. Garden City, New York: Anchor Press.

Friedmann, J. (1987). Planning in the public domain: From knowledge to action. Princeton University Press.

Friedmann, J. (2003). Why do planning theory? Planning Theory, 2(1), 7-10.

Friedmann, J. (2011). Insurgencies: Essays in planning theory. Routledge.

Hamann, R. (2003). Mining companies' role in sustainable development:

The'why'and'how' of corporate social responsibility from a business perspective. Development Southern Africa, 20(2), 237-254.

Hedin, L. T., \& Ranängen, H. (2017). Community involvement and development in Swedish mining. The Extractive Industries and Society, 4(3), 630-639.

Jenkins, H., \& Yakovleva, N. (2006). Corporate social responsibility in the mining industry: Exploring trends in social and environmental disclosure. Journal of Cleaner Production, 14(3), 271-284. 
https://doi.org/10.1016/j.jclepro. 2004.10.004

Joseph, C., Gunawan, J., Sawani, Y., Rahmat, M., Avelind Noyem, J., \& Darus, F. (2016). A comparative study of anticorruption practice disclosure among Malaysian and Indonesian corporate social responsibility (CSR) best practice companies. Journal of Cleaner Production, 112, 28962906.

Kartikawangi, D. (2017). Symbolic convergence of local wisdom in cross-cultural collaborative social responsibility: Indonesian case. Public Relations Review, 43(1), 35-45.

Kemp, D. (2010). Community relations in the global mining industry: Exploring the internal dimensions of externally orientated work. Corporate Social Responsibility and Environmental Management, 17(1), 1-14.

Kriyantono, R. (2015). Public Relations and Corporate Social Responsibility in Mandatory Approach Era in Indonesia. Procedia - Social and Behavioral Sciences, 211, 320327.

https://doi.org/10.1016/j.sbspro.2 015.11 .041

Ranängen, H. (2015). Stakeholder management in reality: Moving from conceptual frameworks to operational strategies and interactions. Sustainable Production and Consumption, 3, 21-33.

Ranängen, H. (2017). Stakeholder management theory meets CSR practice in Swedish mining. Mineral Economics, 30(1), 1529.

Ranängen, H., \& Zobel, T. (2014). Revisiting the 'how' of corporate social responsibility in extractive industries and forestry. Journal of Cleaner Production, 84, 299312.

Sager, T. (1993). Paradigms for planning: A rationality-based classification. Palnning Theory, 9, 79-118.

Sujarto, D. (1988). Perkembangan teori perencanaan. Jurusan Teknik Planologi, FTSP, ITB, Bandung.

Taufiq, M., Kombaitan, B., \& Putro, H. P. H. (2018). CSR, suatu refleksi perencanaan transaktif: Perspektif filsafat ilmu pengetahuan. TATALOKA, 20(2), 136-147.

Taylor, N. (1998). Urban planning theory since 1945. SAGE.

Tourky, M., Kitchen, P., \& Shaalan, A. (2019). The role of corporate identity in CSR implementation: An integrative framework. 
Journal of Business Research, S0148296319301365.

https://doi.org/10.1016/j.jbusres. 2019.02.046

Waagstein, P. R. (2011). The mandatory corporate social responsibility in Indonesia: Problems and Implications.
Journal of Business Ethics, 98(3), 455-466.

Yiftachel, O. (1989). Towards a new typology of urban planning theories. Environment and Planning B: Planning and Design, 16(1), 23-39. 